\title{
KESIAPAN GURU MADRASAH DI KOTA SEMARANG DALAM MENGHADAPI PELAKSANAAN PPG (PENDIDIKAN PROFESI GURU)
}

\author{
Amin Farih \\ Fakultas Ilmu Tarbiyah dan Keguruan UIN Walisongo \\ am.farih@gmail.com
}

Professional Teacher Education (PTE/PPG) can be regarded as a program to improve the competence of today's most important teacher. This program is not solely the learning process of the teachers, but also as a starting point increase teachers' welfare through the provision of teaching certificate and allowances. However, the level of preparedness of teachers to plan the holding of Professional Teacher Education (PTE/PPG) is still low. The mechanism and all the provisions of the Professional Teacher Education (PTE/PPG) is not understanded, the teacher could not prepare him to adapt. Therefore, the implementation of Professional Teacher Education should involve at least four (4) It is important to note ; First, Improved readiness and support of teachers. Second, socialization widely. Third, the accuracy of the allocation of time. Fourth, the full support of the government. If the four components are met then automatically readiness of teachers on the implementation of Professional Teacher Education (PTE/PPG) will go well. 
$2 \mid$ Amin Farih

\section{A. Pendahuluan}

Program sertifikasi guru menurut rencana pada tahun 2014 agar berubah pola penilaiannya dari portofolio menjadi Pendidikan Profesi Guru (PPG). Hal ini sesuai dengan amanat regulasi pendidikan yang berlaku di Indonesia. Dalam pasal 31 ayat (3) Undang-undang Dasar tahun 1945 yang telah diamandemen, menyatakan bahwa pemerintah mengusahakan dan menyelenggarakan satu sistem pendidikan nasional, yang meningkatkan keimanan dan ketaqwaan serta akhlak mulia dalam rangka mencerdaskan kehidupan bangsa, yang diatur dengan undang-undang.

Untuk melaksanakan ketentuan tersebut pemerintah telah melakukan berbagai usaha, termasuk menerbitkan Undang-undang Sistem Pendidikan Nasional (UURI Nomor 20/ 2003), Undang-Undang Guru dan Dosen (UU RI Nomor 14/2005) dan berbagai peraturan perundangan lainnya, yang melihat peranan strategis guru dan dosen dalam peningkatan mutu pendidikan. Guru dipandang sebagai jabatan profesional dan karena itu seorang guru harus disiapkan melalui pendidikan profesi.

Mengacu pada Undang-undang Nomor 20 tahun 2003 tentang Sistem Pendidikan Nasional pasal 3, tujuan umum pendidikan profesi guru adalah menghasilkan calon guru yang memiliki kemampuan mewujudkan tujuan pendidikan nasional, yaitu mengembangkan potensi peserta didik agar menjadi manusia yang beriman dan bertakwa kepada Tuhan Yang Maha Esa, berakhlak mulia, sehat, berilmu, cakap, kreatif, mandiri, dan menjadi warga negara yang demokratis serta bertanggung jawab. Salah satu cara untuk menuju itu adalah dengan PPG.

Tujuan khusus PPG adalah menghasilkan calon guru yang memiliki kompetensi merencanakan dan melaksanakan proses pembelajaran, menilai hasil pembelajaran, melakukan pembimbingan dan pelatihan peserta didik pada pendidikan anak usia dini jalur pendidikan formal, pendidikan dasar, dan pendidikan menengah serta melakukan penelitian.

Berdasarkan data EMIS Depag RI tahun 2004 di Jawa Tengah terdapat sejumlah besar madrasah baik negeri maupun swasta. Adapun rinciannya sebagai berikut: MI Negeri berjumlah 106 dan swasta 3.663 madrasah, MTs negeri berjumlah 116 dan swasta 1.226, sedangkan MA Negeri 61 dan swasta 329. Sementara data guru madrasah di Jawa Tengah dapat dipaparkan sebagai berikut: guru MI PNS 7.914 orang dan non-PNS 23.829 orang, guru MTs PNS 3.390 orang dan non-PNS 23.208 orang, dan guru MA PNS 1.539 orang dan non-PNS 7.466 orang. Secara lebih komprehensif, keadaan guru madrasah serta guru PAI di sekolah umum di Jawa Tengah sesuai data Departemen Agama Pusat tahun 2004 dapat dijabarkan sebagai berikut: MI (31.743 orang), MTs (26.598 orang), MA (9.005 orang), SD (18.357 orang), SMP (2.622 orang) dan SMA (1.653 orang). Salah satu Kota/Kabupaten yang perlu mendapat perhatian untuk diteliti adalah Kota Semarang sebagai ibukota provinsi Jawa Tengah.

Diantara sekian banyak guru PAI itu masih banyak yang belum mengikuti sertifikasi guru pola portofolio. Sehingga ketika kebijakan pemerintah dirubah dengan pola PPG, maka mereka akan mengikuti PPG tersebut. Maka diperlukan penelitian mendalam terkait Respon dan Kesiapan Guru Madrasah dalam Menghadapi Pelaksanaan Pendidikan Profesi Guru (Studi di Kota Semarang). 


\section{B. Landasan Yuridis Formal Pelaksanaan Pendidikan Profesi Guru}

Sesuai dengan Undang-Undang No. 20 th. 2003: Sisdiknas, Bab XI, ps. 39 ayat 2E, guru merupakan tenaga profesional yang bertugas merencanakan dan melaksanakan proses pembelajaran, menilai hasil pembelajaran, melakukan pembimbingan dan pelatihan, serta melakukan penelitian dan pengabdian kepada masyarakat. Agar tugas tersebut dapat ditunaikan dengan baik guru berkewajiban: (a) menciptakan suasana pendidikan yang bermakna, menyenangkan, kreatif, dinamis, dan dialogis; (b) mempunyai komitmen secara profesional untuk meningkatkan mutu pendidikan; dan (c) memberi teladan dan menjaga nama baik lembaga, profesi, dan kedudukan sesuai dengan kepercayaan yang diberikan kepadanya.

Sebagai imbal balik dari tugas dan kewajiban guru yang berat tersebut guru berhak memperoleh: (a) penghasilan dan jaminan kesejahteraan sosial yang pantas dan memadahi; (b) penghargaan sesuai dengan tugas dan prestasi kerja; (c) pembinaan karier sesuai dengan tuntutan pengembangan kualitas; (d) perlindungan hukum dalam melaksanakan tugas dan hak atas hasil kekayaan intelektual; (e) kesempatan untuk menggunakan sarana, prasarana, dan fasilitas pendidikan untuk menunjang kelancaran pelaksanaan tugas. (UU No. 20 th. 2003: Sisdiknas, Bab XI, ps. 40 ayat 1)

Agar hak dan kewajiban guru dapat dipenuhi secara seimbang maka pendidik harus memiliki kualifikasi akademik dan kompetensi sebagai agen pembelajaran, sehat jasmani dan rohani, serta memiliki kemampuan untuk mewujudkan tujuan pendidikan nasional. Kualifikasi akademik yang dimaksudkan adalah tingkat pendidikan minimal yang harus dipenuhi oleh seorang pendidik yang dibuktikan dengan ijazah dan/atau sertifikat keahlian yang relevan sesuai ketentuan perundang-undangan yang berlaku. Sedangkan kompetensi sebagai agen pembelajaran pada jenjang pendidikan dasar dan menengah serta pendidikan anak usia dini meliputi: kompetensi pedagogik; kompetensi kepribadian; kompetensi profesional; dan kompetensi sosial. (UU No. 14 tahun 2005, UUGD, Bab IV pasal 8, 9 dan 10; lihat juga PP No. 19 th. 2005: Standar Nasional Pendidikan Bab VI).

Guru yang profesional dan berkompenten harus memiliki sertifikat pendidik. Sertifikat pendidik dalam jabatan tersebut dapat ditempuh melalui dua jalur yaitu: 1) uji kompetensi untuk memperoleh sertifikat pendidik dan; 2) pemberian sertifikat pendidik secara langsung. (Permendiknas No.10 tahun 2009 pasal 2 ayat 1). Pada dasarnya uji kompetensi atau pemberian langsung tersebut adalah untuk memperoleh sertifikat pendidik sebagai guru profesional. Sertifikat tersebut juga dapat diperoleh melalui program pendidikan profesi yang diselenggarakan oleh perguruan tinggi yang memiliki program pengadaan tenaga kependidikan yang terakreditasi, baik yang diselenggrakan oleh pemerintah maupun masyarakat dan ditetapkan oleh pemerintah. (PP No. 74 tetang Guru bagian kedua pasal 4 ayat 1).

Secara yuridis formal dapat dilacak bahwa program Pendidikan Profesi Guru (PPG) dilaksanakan berdasarkan pada perundangan dan peraturan yang berlaku di Indonesia yang meliputi: Undang-Undang Dasar 1945 dan perubahannya, Undang Undang Nomor 20 Tahun 2003 tentang Sistem Pendidikan Nasional, Undang Undang Nomor 14 Tahun 2005 tentang 
Guru dan Dosen, Peraturan Pemerintah Nomor 19 tahun 2005 tentang Standar Nasional Pendidikan. Ditegaskan dalam Undang-undang RI No. 14 Tahun 2005 Tentang Guru dan Dosen, bahwa: Guru adalah pendidik profesional dengan tugas utama mendidik, mengajar, membimbing, mengarahkan, melatih, menilai, dan mengevaluasi peserta didik pada pendidikan anak usia dini jalur pendidikan formal, pendidikan dasar, dan pendidikan menengah (UU No. 14 th 2005 Tentang Guru \& Dosen, Bab I Pasal 1 ayat 1). Agar tugas tersebut dapat ditunaikan dengan baik, maka guru berkewajiban: (a) menciptakan suasana pendidikan yang bermakna, menyenangkan, kreatif, dinamis, dan dialogis; (b) mempunyai komitmen secara profesional untuk meningkatkan mutu pendidikan; dan (c) memberi teladan dan menjaga nama baik lembaga, profesi, dan kedudukan sesuai dengan kepercayaan yang diberikan kepadanya (UU RI No. 20 Tahun 2003 Tentang Sisdiknas, Bab XI, ps. 40 ayat 2)

Sebagai imbal balik dari tugas dan kewajiban guru yang berat tersebut guru berhak memperoleh: (a) penghasilan dan jaminan kesejahteraan sosial yang pantas dan memadahi; (b) penghargaan sesuai dengan tugas dan prestasi kerja; (c) pembinaan karier sesuai dengan tuntutan pengembangan kualitas; (d) perlindungan hukum dalam melaksanakan tugas dan hak atas hasil kekayaan intelektual; (e) kesempatan untuk menggunakan sarana, prasarana, dan fasilitas pendidikan untuk menunjang kelancaran pelaksanaan tugas (UU RI No. 20 Tahun 2003 Tentang Sisdiknas, Bab XI, ps. 40 ayat 1)

Selanjutnya ditegaskan bahwa agar hak dan kewajiban guru dapat dipenuhi secara seimbang maka pendidik harus memiliki kualifikasi akademik dan kompetensi sebagai agen pembelajaran, sehat jasmani dan rohani, serta memiliki kemampuan untuk mewujudkan tujuan pendidikan nasional. Kualifikasi akademik yang dimaksudkan adalah tingkat pendidikan minimal yang harus dipenuhi oleh seorang pendidik yang dibuktikan dengan ijazah dan/atau sertifikat keahlian yang relevan sesuai ketentuan perundang-undangan yang berlaku. Sedangkan kompetensi sebagai agen pembelajaran adalah kemampuan yang harus dimiliki untuk mengelola pembelajaran pada jenjang pendidikan dasar dan menengah serta pendidikan anak usia dini yang meliputi: kompetensi pedagogik, kompetensi kepribadian, kompetensi profesional, dan kompetensi sosial. (UU RI No. 14 Tahun 2005, Tentang Guru \& Dosen, Bab IV Pasal 8, 9 dan 10; lihat juga PP No. 19 Tahun 2005 Tentang Standar Nasional Pendidikan, Bab VI).

Untuk memenuhi tuntutan yuridis tersebut di atas maka kegiatan Pendidikan Profesi Guru (PPG) sangat diperlukan. Kegiatan tersebut merupakan proses pembuktian bahwa seorang guru telah memenuhi persyaratan yang ditentukan oleh peraturan perundang-undangan. Proses pembuktian tersebut diantaranya melalui suatu uji kompetensi. Dengan proses semacam itu maka akan banyak manfaat yang bisa diambil di anataranya: (1) melindungi guru dari praktekpraktek yang tidak kompeten yang dapat merusak citra profesi guru (2) melindungi masyarakat dari praktek pendidikan yang tidak berkualitas dan profesional. Dalam kerangka pelaksanaan Pendidikan Profesi Guru (PPG) tersebut, maka akhirnya diterbitkan Permendiknas No. 8 tahun 2009 tentang Program Pendidikan Profesi Guru (PPG) 
Untuk mewujudkan guru yang memiliki kualifikasi akademik dan kompetensi tersebut diperlukan adanya lembaga pendidikan tenaga kependidikan (LPTK) yang dapat memberi bekal baik pengetahuan maupun ketrampilan yang relevan dengan proses pembelajaran kepada para calon guru atau guru dalam jabatan. Di samping itu LPTK juga diharapkan dapat memberikan garansi kepada para pengguna lulusan, bahwa guru yang dihasilkannya betul-betul memiliki kualifikasi dan kompetensi sebagai agen pembelajaran.

Untuk itu sebuah LPTK harus mengembangkan dua kegiatan pokok yaitu pendidikan profesi dan uji kompetensi. Pendidikan profesi adalah pendidikan tinggi setelah program sarjana yang mempersiapkan peserta didik untuk memiliki pekerjaan dengan persyaratan keahlian khusus. Program ini mempersiapkan lulusan S1 baik kependidikan maupun non kependidikan yang memiliki bakat dan minat menjadi guru agar menguasai kompetensi guru secara utuh sesuai dengan standar nasional pendidikan sehingga dapat memperoleh sertifikat pendidik profesional pada pendidikan anak usia dini, pendidikan dasar, dan pendidikan menengah (Permendiknas. No.8 tahun 2009). Oleh karena itu, program ini sangat penting bagi peningkatan kompetensi guru dan mutu pendidikan pada waktu yang akan datang.

\section{Pendidikan Profesi Guru Dan Peningkatan Profesionalitas Guru}

\section{Guru Sebagai Profesi}

Guru merupakan salah satu faktor penentu kualitas pendidikan. Bila Gurunya memiliki kualitas akademik, berkompeten dan profesional, maka diharapkan proses pendidikan yang berjalan dapat optimal dan menghasilkan out put lulusan yang kompetitif. Sebaliknya, bila Guru tersebut tidak memenuhi kualitas akademik, tidak berkompeten dan tidak profesional maka keseluruhan proses pendidikan tidak akan optimal. Untuk dapat menghasilkan Guru yang profesional maka upaya peningkatan dan pengembangan kompetensi Guru mutlak diperlukan. Sebelum membahas bagaimana mengembangkan kompetensi guru, perlu dikemukakan terlebih dahulu, sebenamya apa yang dimaksud dengan sebuah profesi dan Guru yang profesional itu?

Profesi dapat diartikan sebagai suatu pekerjaan atau jabatan yang sesuai dengan keahliannya (expertise). Ini berarti suatu pekerjaan/jabatan itu harus dikerjakan oleh orang yang sudah terlatih/disiapkan untuk melakukan pekerjaan tersebut. Ciri-ciri profesi adalah: pertama, profesi merupakan seperangkat keterampilan yang dikembangkan secara khusus melalui seperangkat norma yang dianggap cocok dalam suatu masyarakat; kedua, seorang profesional dituntut untuk memiliki landasan pengetahuan dan keterampilan yang didapatkan dalam waktu yang panjang selama pendidikan dan pelatihan, dan ketiga, seorang profesional harus berorientasi pada usaha memberikan layanan ahli serta dituntut untuk dapat mengevaluasi kerjanya sebagai balikan bagi upaya peningkatan (Nyoman Dentes, 1996). ${ }^{1}$

1 Subijanto, "Pemantauan Tenaga Kependidikan TK, SO, dan SOLB di Kabupaten Badung, Propinsi Bali" dalam Portal Informasi Pendidikan di Indonesia, (Jakarta: Balitbang Oikdasmen Oikti PLSP Kebudayaan, Oepartemen Pendidikan Nasional, 200]), h.5. Sebagaimana diakses melalui www.depdiknas.go.id. 
Nyoman Dentes menambahkan bahwa para ahli profesional di Indonesia merumuskan ciriciri utama profesi sebagai berikut: pertama, memiliki fungsi dan signifikansi sosial yang crucial. Kedua, adanya tuntutan penguasaan keahlianl keterampilan sampai tingkatan tertentu. Ketiga, memiliki perolehan keahlian/keterampilan tersebut bukan hanya dilakukan secara rutin, tetapi melalui pemecahan masalah atau penanganan situasi krisis melalui penggunaan metode ilmiah. Keempat, memiliki batang tubuh disiplin ilmu yang jelas, sistematis dan ekplisit, dan kelima, penguasaan profesi membutuhkan masa pendidikan yang relatif lama, pada jenjang perguruan tinggi. ${ }^{2}$

Menurut Encyclopedi Americana No. 28, disebutkan bahwa profesi merupakan suatu jabatan atau pekerjaan profesional bila yang bersangkutan minimal mendapat pendidikan 1 tahun setelah SMA, dimana: pertama, proses pendidikan yang ditempuh merupakan wahana bagi sosialisasi nilai-nilai profesional di kalangan siswa yang mengikutinya. Kedua, dalam memberikan pelayanan kepada masyarakat/klien, seorang profesional berpegang teguh kepada kode etik, yang pelaksanannya dikontrol oleh organisasi profesi, dan setiap pelanggaran kode etik dapat dikenakan sangsi. Ketiga, anggota suatu profesi mempunyai kebebasan untuk menetapkan judgement sendiri dalam menghadapi atau memecahkan sesuatu dalam lingkup kerjanya. Keempat, tanggung jawab profesional adalah komitmen kepada profesi berupa pelayanan sebaikbaiknya kepada masyarakat/klien dan praktik profesional itu otonom dari campur tangan pakar luar, dan kelima, sebagai imbalan dari proses pendidikan dan latihannya yang lama dan komitmen pada seluruh jasaJpekerjaannya sehingga seorang profesional mempunyai prestise yang tinggi di masyarakat dan oleh karenanya berhak mendapatkan imbalan yang layak atau dengan kata lain "bertanda jasa".

Ciri-ciri pekerjaan yang berkualifikasi profesional adalah: memerlukan persiapan atau pendidikan khusus (ijazah, sertifikat, pelatihan, dan sebagainya), membutuhkan pendidikan prajabatan, dan memenuhi persyaratan (administratif, dan akademik). ${ }^{3}$ Sedang kriteria pendidik profesional adalah: memberi pelayanan kepada masyarakat kampus, mengikuti pelatihan, memberi sumbangan bagi kode etik, tergabung dalam asosiasi profesi, melakukan publikasi karya ilmiah, mengikuti ujian dalam pendidikan tertentu dan pembatasan perilaku.

Berdasarkan uraian di atas, hal mendasar yang semestinya dipahami berkaitan dengan profesi adalah kepedulian yang didasari atas kearifan atau pengabdian berdasarkan keahlian demi kemaslahatan orang lain. Frank. H. Blackington menyatakan: a profession must satisfy an indispensable social need and be based upon well established and socially acceptable scientific principles, yakni bahwa sebuah profesi harus memenuhi kebutuhan masyarakat yang sangat diperlukan dan didasarkan pada prinsip-prinsip ilmiah yang diterima oleh masyarakat. Senada dengan itu, Nyron Lieberman menyatakan bahwa tekanan utama seorang profesional adalah terletak pada pengabdian yang harus dilaksanakan dari pada keuntungan ekonomi. ${ }^{4}$ Berkaitan dengan karakteristik profesional tersebut, pertanyaan yang patut diajukan adalah sudah optimalkah

\section{2 lbid.}

3 A. Samana, Profesionalisme Keguruan, (Yogyakarta: Penerbit Kanisius, 1994), h.27-29.

4 Jusuf Amir Feisal, Reorientasi Pendidikan Islam, (Bandung: Gema lnsani Pers, 1995), h.173-175. 
tenaga kependidikan nasional kita dalam melaksanakan tugasnya sebagai profesi?

Dengan demikian, Guru yang profesional adalah mereka yang memiliki kemampuan profesional dengan berbagai kapasitasnya sebagai pendidik. Studi yang dilakukan oleh Ace Suryani menunjukkan bahwa Guru yang bermutu dapat diukur dengan lima indikator, yaitu: pertama, kemampuan profesional (professional capacity), sebagaimana terukur dari ijazah, jenjang pendidikan, jabatan dan golongan, serta pelatihan. Kedua, upaya profesional (professional efforts), sebagaimana terukur dari kegiatan mengajar, pengabdian dan penelitian. Ketiga, waktu yang dicurahkan untuk kegiatan profesional (teacher's time), sebagaimana terukur dari masa jabatan, pengalaman mengajar serta lainnya. Keempat, kesesuaian antara keahlian dan pekerjaannya (link and match), sebagaimana terukur dari mata kuliah yang diampu, apakah telah sesuai dengan spesialisasinya atau tidak, serta kelima, tingkat kesejahteraan (prosperiousity) sebagaimana terukur dari upah, honor atau penghasilan rutinnya. Tingkat kesejahteraan yang rendah bisa mendorong seorang pendidik untuk melakukan kerja sambilan, dan bilamana kerja sambilan ini sukses, bisa jadi profesi mengajarnya berubah menjadi sambilan.

Guru yang profesional amat berarti bagi pembentukan sekolah unggulan. Guru profesional memiliki pengalaman mengajar, kapasitas intelektual, moral, keimanan, ketaqwaan, disiplin, tanggungjawab, wawasan kependidikan yang luas, kemampuan manajerial, trampil, kreatif, memiliki keterbukaan profesional dalam memahami potensi, karakteristik dan masalah perkembangan peserta didik, mampu mengembangkan rencana studi dan karir peserta didik serta memiliki kemampuan meneliti dan mengembangkan kurikulum.

Khusus untuk Guru agama Islam, perlu diperhatikan penguasaan bidang agama Islam dan ketaatan dalam beribadah maupun amaliah sehingga ia mampu mengintegrasikan nilainilai Islam ke dalam setiap mata kuliah yang diajarkannya (integrated curriculum) dan mampu menciptakan iklim dan kultur kampus (campus climate and campus culture) yang Islami. Selain berkepribadian terpadu, cakap, bertanggung jawab, teladan, dan kompeten di bidangnya, Guru agama Islam yang profesional dituntut untuk beriman, bertaqwa, ikhlas, dan berakhlak mulia. ${ }^{5}$ Al-Abrasyi menambahkan, bahwa Guru dalam pendidikan Islam hendaklah memiliki sifat zuhud, bersih, ikhlas, pemaaf, berperilaku kasih sayang pada murid layaknya orang tua pada anak, mengetahui watak murid, dan menguasai pelajaran. ${ }^{6} \mathrm{Al}$-Abrasyi memandang bahwa Guru adalah spiritualfather atau bapak-rohani bagi seorang murid. Gurulah yang memberi santapan jiwa dengan ilmu dan akhlak. Pendek kata, Guru agama Islam dituntut untuk memiliki sifatsifat utama (jadlilah) dan karakter positif sebagai pendidik (akhlak al-karimah). Seterusnya, Guru agama Islam hendaknya menuntut ilmu tidak sekedar thalabu al- ilmi li dzat al- ilmi atau science for science, melainkan thalabu al- 'ilmi li mardlatillah ${ }^{7}$. Memang, semakin detail

5 Ramayulis, Ilmu Pendidikan Islam, (Jakarta: Kalam Mulia, 1994), h. 37-45.

6 Muhammad 'Athiyah al-Abrasyi, "al-Tarbiyah al-Islamiyah"(terjemah) dalam Dasar-Dasar Pokok Pendidikan Islam, (Jakarta: Bulan Bintang, 1993), h.136-141. lihat juga Ahmad Tafsir, IImu Pendidikan dalam Perspektif Islam, (Bandung: Remaja Rosdakarya, 1994), h.77-85. lihat juha Muhaimin, Pemikiran Pendidikan Islam: Kajian Filosofik dan Kerangka Dasar Operasionalisasinya, (Bandung: Trigenda Karya, 1993), h.176-177.

7 Ibid. h. 136. 
kualifikasi seorang Guru agama Islam diuraikan, semakin sulit mendapatkan figure tersebut. Akan tetapi, sebagai acuan untuk merealisasikan pendidikan yang unggul, berbagai karakter dan tipologi Guru agama Islam yang profesional tadi, merupakan suatu keniscayaan untuk dapat dicapai, dan oleh karenanya perlu dilakukan pembinaan secara terus-menerus.

Figur ideal Guru agama Islam adalah Nabi. Sebab, Nabi merupakan teladan bagi umatnya, sekaligus sosok Guru yang ideal, karena Nabi membina aspek material-spritual manusia. ${ }^{8}$ Maka, Guru agama Islam mengikuti pola pendidikan prophetic yang merefleksikan nilai-nilai ketuhanan (teo-sentris) dengan inti tauhid. Pendidikan yang tauhidik ini ketika diimplementasikan dalam kehidupan sehari-hari, tidak bisa meremehkan aspek antropo-sentris, sehingga dimensi pendidikan Islam mencakup totalitas teo-antropo-sentris. Pembenaran terhadap aspek ketuhanan, atau teo-sentris tadi, diambil oleh Guru agama Islam dari sumber wahyu (revealed and perennial knowledge), sementara konsepsinya terhadap kealaman dan kemanusiaan dicapai melalui sumber rasional (acquired knowledge). Ringkasnya, seorang Guru agama Islam itu memadukan dimensi material dengan spiritual, jasmani dengan rohani, lahir dengan batin, ilmu dengan iman, dan duniawi dengan ukhrawi.

Jadi, seorang Guru agama Islam mempunyai nilai tambah (added value), bila dibandingkan dengan pendidik pada umumnya, dari aspek kapasitas keberagamaanya (religious competency). Untuk alasan inilah, Guru agama Islam dipersyaratkan tidak hanya berperan sebagai seorang sarjana, melainkan juga sebagai orang yang berkepribadian utama, yakni seorang yang perilakunya menjadi teladan bagi para muridnya. Soalnya bukan sekedar apa yang dia ajarkan, tetapi juga apa yang ia kerjakan, cara ia melakukan, dan sikapnya baik di dalam maupun di luar kelas, dimana semua itu mestilah bersesuaian dengan perilaku ideal yang dapat diterima oleh para muridnya tanpa ragu. ${ }^{9}$

Al-Ghazali cukup konprehensif dalam menjelaskan karakteristik ideal Guru agama Islam tersebut atas dasar kode etik yang patut dimilikinya. Bagi al-Ghazali, Guru agama Islam seharusnya menerima segala problem anak didik dengan hati dan sikap yang terbuka lagi tabah,

8 QS. AI-Ahzab (33:21): "Sesungguhnya telah ada pada (diri) Rasulullah itu suri teladan yang baik bagimu (yaitu) bagi orang yang mengharap (rahmat) Allah dan (kedatangan) hari kiamat dan dia banyak menyebut Allab”. Nabi sebagai teJadan yang patut ditiru oleh umatnya ini berlaku secara umum, tidak hanya Nabi Muhammad saja. Tiap umat meneladani Nabinya. Dalam ayat yang lain disebutkan bahwa Nabi lbrahim patut diteladani. Lihat QS. An-NahJ (16: 120): "Sesungguhnya Ibrahim adalah seorang imam yang dapal dijadikan leladan lagi paluh kepada Allah dan hanif Dan sekali-kali bukanlah dia termasuk orangorang yang mempersekulukan (Tuhan)”, juga QS. AJ-Mumtahanah (60:6): "Sesungguhnya pada mereka itu (Ibrahim dan umalnya) ada leladan yang baik bagimu; (yailu) bagi orang yang mengharap (pahala) Allah dan (keselamalan pada) Hari kemudian. Dan barangsiapa yang berpaling, maka sesungguhnya Allah, Dialah Yang Maha Kaya lagi terpuji”.

9 Lihat Syed Sajjad Husein dan Syed Ali Ashraf, Crisis in Muslim Education, Jeddah: Hodder and Stoughton, Kin Abdu\Aziz University, 1979), h.104. 
bersikap penyantun dan penyayang (QS. 3: 159), ${ }^{10}$ tidak angkuh terhadap sesama (QS. 53:32), ${ }^{11}$ tawadlu (QS. 15:88), ${ }^{12}$ taqarrub (QS.98:5), ${ }^{13}$ menghindari aktivitas yang sia-sia, lemah lembut pada anak, tidak pemarah, tidak menakutkan bagi anak, memperhatikan pertanyaan mereka, menerima kebenaran dari anak yang membantahnya, mencegah anak mempelajari ilmu yang berbahaya, serta mengaktualisasikan ilmu yang dipelajarinya. ${ }^{14}$

Sayangnya, konsepsi Guru agama Islam ideal seperti itu harus disepelekan akibat perubahan modernitas dan pergeseran sosial-budaya. Profesionalisme kadang kala dimaknai secara sempit dengan slogan ada upah ada kerja, padahal, pekerja keras dan berat belum tentu mendapat upah yang setimpal dan layak. Bisa jadi, pekerta tanpa keringat mendapat upah jauh lebih besar dari selainnya. Pekerja profesional juga terlanjur dilembagakan (institutionalized), akibatnya pendidik yang secara individual patut disebut profesional, tidak diakui. Upah dan pengakuan, sebagaimana diuraikan terdahulu, memang menjadi kriteria profesionalisme pendidik, namun implementasinya tidak hanya menekankan kedua hal tersebut secara sepihak dengan mengesampingkan kriteria lainnya, semisal professional capacity, professional efforts, link and match, dan bagi Guru agama Islam masih ada nilai tambah lagi, yaitu iman, taqwa, ikhlas, tawaddlu, taqarrub, dan lain sebagainya.

\section{Performance Guru}

Perilaku Guru dirancang untuk menentukan seberapa baik para Guru dapat melaksanakan keterampilan mengajar minimum tertentu yang dipandang secara umum penting bagi pembelajaran efektif. Untuk mengukur efektifitas kemampuan perilaku Guru tersebut disusunlah instrumen uji kompetensi yang disebut dengan Teacher Performance Assessment Instruments atau TPAI. Sebagai sebuah pengukuran langsung bagi Guru yang sedang mengajar, TPAI ini berangkat lebih dari sekedar tes tertulis (paper and pen test), dimana dari situ kesimpulan dapat dibuat tentang bagaimana kualitas mengajarnya melalui pengetahuan Guru tentang konsep pendidikan pada umumnya. Sementara instrumen lainnya digunakan untuk mengukur apa yang diketahui oleh Guru tentang materi, siswa, dan bagaimana pembelajaran tersebut dilaksanakan. Di sini TPAI menjadi sarana yang tepat untuk mengukur kemampuan Guru yang

10 QS. Ali Imran (3: 159): "Maka disebabkan rahmat Allah-lah kamu berlaku lemah lembut terhadap mereka. Sekiranya kamu bersikap keras lagi berhati kasar, tentulah mereka menjauhkan diri dari sekelilingmu. Karena itu maajkanlah mereka, mohonkanlah ampunan bagi mereka, dan bermusyawarahlah dengan mereka dalam urusan ini. Kemudian apabila kamu telah membulatkan tekad, maka bertawakallah kepada Allah. Sesungguhnya Allah menyukai orang-orang yang bertawakkal kepada-Nya"

11 QS. An-Najrn (53:32): "(Yaifu) orang yang menjaubi dosa-dosa besar dan perbuatan keji yang selain dari kesalahan-kesalahan kecil. Sesungguhnya Tuhanmu maha luas ampunan-Nya. Dan Dia lebih mengetahui (tentang keadaan)mu ketika Dia menjadikan kamu dari tanah dan ketika kamu masihjanin dalam perut ibumu; maka janganlah kamu mengatakan dirimu suci. Dialah yang paling mengetahui tentang orang yang bertakwa ".

12 QS. AI-Hijr (15:88): "Janganlah sekali-kali kamu menunjukkan pandanganmu kepada kenikmatan hidup yang telah Kami berikan kepada beberapa golongan di antara mereka (orang-orang kafir itu), dan janganlah kamu bersedih hati terhadap mereka dan berendah dirilah kamu terhadap orang-orang yang beriman".

13 QS. AI-Bayyinah (98:5): "Padahal mereka tidak disuruh kecuali supaya menyembah Allah dengan memurnikan ketaatan kepada-Nya dalam (menjalankan) agama dengan lurus, dan supaya mereka mendirikan shalat dan menunaikan zakat,' dan yang demikian ifulah agama yang lurus ".

14 Muhaimin, Op. Cit., h.175. 
sedang mengajar.

TPAI ini dirancang untuk pemberian sertifikasi mengajar guru dan dapat digunakan melalui berbagai cara, baik secara in-service educational development maupun pre-service teacher educational program. Sebenarnya apa isi instrumen TPAI tersebut? Secara singkat akan dijelaskan berikut ini.

Instrumen TPAI meliputi lima komponen, yaitu: pertama, rencana mengajar dan materi pelajaran guru (Teacher Plans and Materials atau TPM). Fokusnya adalah keterampilan mengajar yang berkaitan dengan persiapan mengajar. Guru yang diuji kompetensinya diminta untuk menyiapkan portofolio untuk satuan pembelajaran. Setelah mempelajari portofolio tersebut dan mewancarainya, para pengumpul data menilai seluruh item komponen yang terkait dengan perencanaan, pemilihan tujuan, dan penentuan bahan dan alat yang dipakai dalam pembelajaran. Kedua, langkah-langkah yang dilakukan oleh Guru di ruang kelas (The Classroom Procedures atau CP). Fokusnya adalah praktik pengajaran langsung di ruang kelas. Para pengumpul data menggunakan instrumen ini untuk mengidentifikasi praktik mengajar guru dalam setting ruang kelas yang sedang berjalan. Karenanya, pengamatan secara langsung di ruang kelas ketika Guru sedang mengajar menjadi sumber penilaian yang utama. Uji kompetensinya menyangkut metode dan teknik mengajar.

Ketiga, kemampuan kepribadian (The Interpersonal Skills atau IS) yang menyatakan kompetensi dalam menciptakan iklim sosial yang menyenangkan, berupa sikap hangat dan bersahabat dalam mengelola interaksi di ruang kelas. Skor uji kompetensi ini juga didasarkan pada pengamatan langsung pada perilaku Guru selama proses pembelajaran di ruang kelas sedang berjalan.

Keempat, standar profesional (The Professional Standards atau PS). Uji kompetensi ini tidak membutuhkan portofolio maupun observasi langsung, sebab tes ini menguji perilaku profesional Guru menyangkut kebijakan dan prosedur sekolah, serta keterlibatannya dalam berbagai kegiatan. Uji kompetensi ini dilakukan melalui interview dengan Guru tersebut, kolega, serta atasannya sebagai sumber utama penilaian.

Kelima, persepsi siswa (The Student Perceptions atau SP). Uji kompetensi ini menilai persepsi siswa terhadap perilaku mengajar gurunya di ruang kelas. Alat penilaiannya meliputi berbagai item yang ada dalam CP dan IS yang disusun sedemikian rupa mudah dipahami oleh siswa. Misalnya saja, siswa ditanya apakah mereka berpendapat bahwa gurunya bersahabat, memahami mereka, atau memotivasi perbuatan siswa. Jawaban siswa bisa berjenjang dari "tidak pernah", "kadang-kadang", sampai pada "sering".

Sedangkan komponen kelima, yaitu Studens Perceptions (SP) instrumen dan indikatomya merupakan perpaduan antara Classroom Procedures (CP) dengan Interpersonal Skills (IS) di atas. Hal itu dilakukan untuk tujuan validasi dan triangulasi dari hasil penilaian guru tersebut. Seluruh komponen, intrumen dan indikator guru di atas bisa dijadikan sebagai salah satu model pemberian sertifikasi. 
Beranjak dari seluruh uraian di atas, dapat dipahami bahwa dalam rangka mewujudkan profesionalisme guru diperlukan serangkaian upaya dan proses peningkatan kualitas akademik, pengembangan kompetensi, pemberian pengakuan dalam bentuk sertifikasi, pemberian insentif yang layak, kesiapan SDM, dukungan politik, hukum, sosial, budaya, serta faktor terkait lainnya.

\section{Desain Program Pendidikan Profesi Guru (PPG)}

Kerangka dasar, struktur kurikulum, dan kurikulum pendidikan profesi Fakultas Ilmu Tarbiyah dan Keguruan IAIN Walisongo mencakup perangkat kompetensi yang dikemas dalam mata kuliah yang mewadahi dan menfasilitasi pengembangan pribadi guru profesional dengan beban belajar 40 SKS.

Adapun beban belajar untuk pendidikan profesi guru Pendidikan Agama Islam adalah sebagai berikut:

a. Untuk lulusan program sarjana (S1) atau diploma empat (D-IV) kependidikan wajib menempuh sebesar $60 \%$ (enam puluh persen) teori dan praktik terkait dengan kompetensi profesional dan $40 \%$ (empat puluh persen) teori dan praktik terkait dengan kompetensi pedagogik; kompetensi kepribadian; dan kompetensi sosial.

b. Untuk lulusan program sarjana (S.1) atau diploma empat (IV) nonkependidikan (dalam studi Islam) wajib menempuh sebesar $60 \%$ (enam puluh persen) teori dan praktik terkait dengan kompetensi pedagogik; kompetensi kepribadian; dan kompetensi sosial, serta $40 \%$ (empat puluh persen) teori dan praktik terkait kompetensi profesional.

c. Selain itu, bagi lulusan sarjana non kependidikan Pendidikan Agama Islam atau non kependidikan baik yang berasal dari Pendidikan Agama Islam atau lainnya wajib mengambil materi matrikulasi sebelum mereka mengikuti program PPG tersebut. Materi matrikulasi disesuaikan dengan latar belakang pendidikan peserta didik untuk dijadikan dasar dalam pelaksaan program PPG.

Bahan kajian pendidikan profesi guru Pendidikan Agama Islam akan tersaji dalam daftar mata kuliah yang terbagi ke dalam 2 (dua) kelompok, meliputi:

a. Mata Kuliah Kependidikan (subject specific pedagogy).

b. Mata Kuliah Profesi Pendidikan Agama Islam (subject enrichment)

\section{E. Kesiapan Guru Agama Islam Menghadapi PPG}

Parameter kesiapan adalah kondisi diri setiap guru dalam rencana menghadapi program PPG. Secara keseluruhan, temuan kami menunjukkan kesiapan guru dalam menghadapi PPG masih sangat rendah. Berdasarkan data statistik, aspek kesiapan guru hanya mendapat nilai 57 , terendah dibanding aspek lainnya. Nilai ini menunjukkan rendahnya prioritas dari guru untuk mengikuti program ini. Tentu saja hal ini akan memberi pengaruh cukup besar pada totalitas guru ketika benar-benar melaksanakan PPG.

Berdasarkan wawancara yang kami lakukan, setidaknya ada 3 faktor dominan yang mempengaruhi ketidaksiapan guru untuk mengikuti PPG. Pertama, faktor kesempatan. Dalam ketentuan perekrutan peserta PPG, disebutkan bahwa perekrutan dilakukan oleh LPTK 
penyelenggara berkonsultasi dengan pemerintah kabupaten/kota. Peserta PPG dibatasi pada jumlah tertentu sesuai dengan kebutuhan dan diutamakan untuk guru yang memiliki kualifikasi tertentu pula. Dengan kuota yang terbatas, maka kesempatan masing-masing individu untuk mengikuti program ini sangat kecil.

Kedua, kendala waktu. Guru yang memiliki jam mengajar tinggi akan sangat kesulitan membagi waktu. Mayoritas responden memilih akhir pekan sebagai pelaksanaan PPG. Namun tentu saja tetap membutuhkan kerja keras untuk bisa mengikuti PPG selama 2 semester penuh. Ketiga, faktor biaya. Kesiapan guru untuk membiayai kegiatan PPG sangat rendah. Mayoritas responden lebih memilih biaya PPG ditanggung pemerintah. Belum lagi kendala biaya transportasi bagi guru yang bertempat tinggal jauh dari lokasi LPTK tempat di mana PPG dilaksanakan.

Yang menarik untuk diperhatikan dalam statistik tingkat kesiapan guru adalah hasilnya yang variatif di setiap jenjang pendidikan. Tingkat kesiapan untuk guru MI sangat rendah dibanding guru di jenjang pendidikan lainnya. Skor untuk guru MI hanya 53 poin, dibanding 61 poin untuk guru MTs dan 56 untuk guru MA. Ini tidak bisa lepas dari tugas guru MI sebagai guru kelas dengan jam mengajar penuh. Ini berbeda dengan tugas guru MTs dan MA sebagai guru mata pelajaran.

Sedangkan berdasarkan klasifikasi jenis kelamin, skor yang ditunjukkan beda tipis, yaitu 59 untuk laki-laki dan 55 untuk perempuan. Jadi, kesiapan guru tidak banyak dipengaruhi faktir gender, yang berarti berkaitan dengan tugas rumah tangga. Faktor kesiapan guru sejauh ini masih banyak dipengaruhi oleh kondisi guru di madrasahnya masing-masing.

Hal ini sebagaimana dituliskan responden dari MI Nurul Islam, Ahmad Syafi'i: “Jika PPG dilaksanakan setiap hari, saya ragu apakah guru-guru MI bisa mengikutinya. Padahal mereka memiliki tugas yang lebih penting di madrasah masing-masing sebagai pendidik. Jika guru lebih mengutamakan PPG, maka justru dia akan meninggalkan tugas utamanya di madrasah”. Skala prioritas yang dipegang oleh guru tetap mengacu pada tugas utamanya. PPG hakikatnya adalah program peningkatan kompetensi yang diorientasikan pada pengembangan kemampuan mengajar. Jadi, program peningkatan kompetensi tidak bisa mengalahkan tugas mengajar itu sendiri.

\section{F. Daya Dukung Guru Agama Islam Terhadap PPG}

Tingkat daya dukung guru sangat berpengaruh dalam tercapainya tujuan umum PPG sebagaimana tercantum dalam pasal 3 Undang-Undang Nomor 20 Tahun 2003, yaitu menghasilkan calon guru yang memiliki kemampuan mewujudkan tujuan pendidikan nasional, yaitu mengembangkan potensi peserta didik agar menjadi manusia yang beriman dan bertakwa kepada Tuhan Yang Maha Esa, berakhlak mulia, sehat, berilmu, cakap, kreatif, mandiri, dan menjadi warga negara yang demokratis serta bertanggung jawab.

Untuk itu dilaksanakan PPG dengan pola pendidikan profesi guna membentuk pribadi yang memiliki keahlian khusus sebagai guru yang profesional. Profesionalitas akan sangat bisa 
dikembangkan dengan optimal manakala guru telah memiliki daya dukung yang positif. Sebagai pengakuan atas kompetensinya, kemudian guru akan mendapatkan sertifikat pendidik yang berarti dia bisa memegang profesi guru sepenuhnya.

Dalam rangka memfasilitasi pelaksanaan Program PPG, telah dilaksanakan berbagai workshop pengembangan standar Isi, Standar kompetensi lulusan dan Panduan PPL Program PPG, telah disusun contoh perangkat RPP untuk mata pelajaran, dan pelatihan fasilitator workshop PPG. Semua ini dilakukan guna mendukung tercapainya tujuan PPG secara optimal. Daya dukung ini tidak semata-mata berasal dari pemerintah, melainkan yang terpenting adalah dari tiap-guru itu sendiri.

Daya dukung guru yang dimaksud adalah segenap modal diri yang dimiliki setiap guru untuk mendukung optimalnya program PPG. Modal ini bisa berupa kualifikasi pendidikan guru, modal ilmu pengetahuan dan keterampilan mengajar yang telah dikuasai, program peningkatan kompetensi yang pernah diikuti, dan masa tugas guru di madrasah masing-masing. Modal-modal ini diharapkan akan mendukung optimalnya PPG karena guru telah memiliki bekal awal untuk dikembangkan.

Saat ini daya dukung guru menunjukkan gejala positif dengan nilai 77 poin. Di samping keterbatasan waktu dan biaya, daya dukung guru terhadap pelaksanaan PPG justru cenderung positif, dan merata di setiap jenjang pendidikan. Respons paling positif ditunjukkan oleh kelompok responden dari guru MA dengan nilai 87. Peningkatan kompetensi diri oleh guru dilakukan dengan mengikuti berbagai pelatihan dan program peningkatan kompetensi guru lainnya. Seperti yang diungkapkan oleh M. Zahri Johan dari MAN 02 Semarang: "Saya mengikuti banyak kegiatan seperti diklat jarak jauh, diklat peningkatan kualitas guru mapel, seminar, pelatihan, dan workshop. Besar pengaruhnya dalam memberikan inspirasi, motivasi, ide, dan skill untuk meningkatkan kualitas pembelajaran" (WG-MA.02.2).

Dalam konteks yang sama, responden lain memberikan tanggapan yang sedikit berbeda, sebagaimana diungkapkan Hadi Suprayitno dari MA Darul Ulum: "Pernah, workshop penyusunan KTSP, workshop media pembelajaran. Pengaruhnya, paling tidak punya gambaran lebih jelas dan mampu mengajar menggunakan media sesuai dengan materi pembelajaran" (WGMA.03.2). Berbeda lagi dengan Taufiq Romadhon dari MTs Al-Asror yang bahkan mengaku belum sama sekali mengikuti kegiatan peningkatan kompetensi guru.

Tiga kutipan di atas paling tidak menandai heterogenitas pengalaman guru dalam upaya meningkatkan kompetensi dirinya. Kutipan pertama menandakan bahwa guru yang bersangkutan telah mengalami banyak pengalaman dalam dunia keselatihan keguruan dan memiliki pengaruh yang sangat besar terhadap pengembangan pola pembelajarannya di dalam kelas. Selain menjadi indikasi keberhasilan pelatihan yang dijalani, guru tersebut memiliki daya dukung yang cukup bagus terhadap program PPG.

Kutipan kedua menyatakan banyaknya pengalaman yang telah didapat oleh guru yang bersangkutan dengan banyaknya pelatihan dan berbagai program peningkatan kompetensi guru. Namun di sini belum tampak adanya pengaruh besar baginya dalam upaya pengembangan 
kompetensi diri. Pengaruh yang didapatkannya baru sebatas tambahan wawasan. Sedangkan responden ketiga sama sekali belum pernah mengikuti program peningkatan kompetensi.

Hal-hal terkait pengalaman kerja, tingkat pendidikan, dan diklat/pelatihan yang telah diikuti memang sangat dominan dalam aspek daya dukung. Terbukti dengan munculnya nilai yang merata dalam data statistik berdasarkan klasifikasi jenis kelamin. Kelompok guru lakilaki dan kelompok guru perempuan sama-sama mendapatkan nilai 75. Sedangkan klasifikasi berdasarkan jenjang pendidikan, kelompok guru MI dan MTs juga mendapat nilai 75.

Guru MA lebih unggul dengan nilai 87 karena ada satu faktor yang dominan di kalangan guru ini, yaitu lamanya masa kerja. guru dengan kematangan pengalaman karena masa pengabdian yang lama, cukup besar jumlahnya. Jika kualifikasi peserta dibatasi pada guru yang telah mengabdi 3-4 tahun, akan sangat mudah menemukannya. Batasan minimal pendidikan guru yang setara $S 1$ juga memberi kontribusi positif tersendiri.

Yang perlu menjadi catatan adalah, tingkat daya dukung ini adalah aspek yang paling dinamis. Artinya, tingkat daya dukung guru bisa berubah sewaktu-waktu secara signifikan manakala dilaksanakan program-program yang mendukung dilakukannya penguatan daya dukung guru.

\section{G. Problematika Kesiapan Guru Dalam PPG}

Secara normatif, Program Pendidikan Profesi Guru (PPG) adalah program pendidikan yang diselenggarakan untuk lulusan S-1 Kependidikan dan S-1/D-IV Non Kependidikan yang memiliki bakat dan minat menjadi guru, agar mereka dapat menjadi guru yang profesional sesuai dengan standar nasional pendidikan dan memperoleh sertifikat pendidik.

Guna mendukung program tersebut berbagai upaya telah dilakukan oleh pemerintah. Namun bukannya tanpa masalah, persiapan yang selama ini dilakukan masih banyak memiliki catatan. Khusus untuk lingkup Kota Semarang, persoalan itu tampak misalnya dalam tingkat responsibilitas guru terhadap PPG. Pemahaman guru terhadap program ini bahkan masih rendah.

Aspek problematika yang kami cantumkan dalam angket mencakup 5 item yang masingmasing mendapat skor tersendiri. Berikut adalah rekap skor angket problematika kesiapan guru yang melibatkan 24 responden.

\section{Rekap Hasil Angket \\ Problematika Kesiapan Guru}

\begin{tabular}{|c|l|c|c|c|}
\hline No & Problematika Kesiapan Guru & Skor & Rata-rata & Nilai \\
\hline 1 & $\begin{array}{l}\text { PPG perlu disosialisasikan kepada Guru terlebih dahulu } \\
\text { teknisnya }\end{array}$ & 90 & 3.7 & 93 \\
\hline 2 & Pembagian waktu mengajar dan PPG & 86 & 3.6 & 90 \\
\hline 3 & Guru yang ikut PPG perlu Cuti Mengajar (izin belajar) & 35 & 1.5 & 38 \\
\hline
\end{tabular}




\begin{tabular}{|c|l|c|c|c|}
\hline 4 & Pembiayaan PPG oleh pemerintah & 92 & 3.8 & 95 \\
\hline 5 & Pembiayaan PPG secara mandiri & 33 & 1.4 & 35 \\
\hline
\end{tabular}

Dari data hasil penelitian kuesioner di atas menunjukkan adanya hasil yang kontras. Selanjutnya dapat dilihat berbagai problematika seputar PPG.

1. Sosialisasi

Sosialisasi PPG masih dipandang minim dan karenanya masih perlu dioptimalkan lagi. Urgensi sosialisasi terletak pada upaya guru untuk mempersiapkan diri. Dengan sosialisasi yang matang, guru akan lebih bisa mempersiapkan diri untuk mendukung tercapainya tujuan PPG. Sejauh ini, pemahaman guru masih sejauh pengertian PPG, dan belum menyentuh halhal substansial, seperti alokasi waktu, beban materi, pembiayaan, dan mekanisme perekrutan. Dengan nilai skor 93, guru hampir menyatakan keharusan untuk dilakukan sosialisasi hingga ke ketentuan teknisnya.

2. Alokasi waktu

Guru yang telah memiliki jam mengajar tinggi harus susah payah membagi waktu dengan PPG. Jika pola sertifikasi hanya membutuhkan waktu beberapa hari, lain halnya dengan PPG yang dilaksanakan dua semester. Itu berarti guru harus sekolah lagi. Dengan beban materi yang cukup banyak, kesiapan fisik dan pikiran juga harus kuat untuk menghadapi kegiatan yang padat ketika mengikuti PPG. Tidak jauh berbeda dengan item sebelumnya, item ini mendapat nilai 90. Artinya, pembagian waktu antara jam mengajar guru dan pelaksanaan PPG harus dikompromikan dengan tepat agar tidak terjadi tumpang tindih tanggung jawab karena pada dasarnya, tugas utama guru adalah mengajar dan PPG adalah sebagai penunjangnya. Sebagaimana diungkapkan S. Ulil Umah dari MA Darul Ulum: "Kendala utamanya adalah waktu, karena di luar tugas mengajar, saya juga punya tanggung jawab rumah tangga” (W.MA.03.2).

3. Pembiayaan

Kebutuhan guru tidak selalu sesuai dengan keadaannya, contohnya adalah masalah pembiayaan. Peningkatan kualitas guru memang menjadi persoalan yang urgen, namun di samping itu kesejahteraan guru, terutama guru honorer belum memadai. Gaji yang diterima belum tentu bisa untuk membiayai PPG, di samping kebutuhan pokok hidupnya. Dengan tingginya biaya PPG, hampir dipastikan guru akan merasa keberatan, idealnya pembiayaan PPG ditanggung oleh pemerintah sebagai tanggung jawab pemerintah dalam meningkatkan kompetensi guru guna tercapainya tujuan pendidikan nasional.

\section{H. Solusi Pelaksanaan PPG}

Seiring perkembangan zaman, guru terus dituntut untuk dapat meningkatkan kualitas dan profesionalitas tugas utamanya, seperti mendidik, mengajar, membimbing, melatih, menilai, dan mengevaluasi hasil belajar peserta didik sebagaimana termaktub dalam UU nomor 14 tahun 2005 tentang guru dan dosen. Guru sebagaimana kita kenal merupakan sebuah jabatan 
profesioanal yang tentunya untuk menuju hal tersebut harus melalui jalur pendidikan yang sesuai yakni kependidikan dan keprofesian. Sehingga kedepan kebutuhan akan guru yang memang memiliki jiwa pendidik dapat terpenuhi dan tentu akan memberikan pengaruh yang sangat positif di dunia penddikan. Guna mewujudkan tujuan tersebut, pemerintah melalui Kementerian Pendidikan Nasional menyusun kebijakan yang disebut Program Pendidikan Profesi Guru (PPG).

Yang perlu disadari adalah bahwa PPG bukanlah satu-satunya program peningkatan kompetensi guru. PPG adalah salah satu program yang khas dan tentu saja memiliki persoalannya sendiri. Untuk mengoptimalkan hasil program PPG sesuai dengan tujuannya, setidaknya perlu diperhatikan berbagai hal berikut.

4. Peningkatan kesiapan dan daya dukung guru

Pemberdayaan kreatifitas guru melalui berbagai program diklat dan pelatihan perlu dimaksimalkan guna menyiapkan guru untuk mengikuti program PPG secara penuh. Dengan begitu PPG akan lebih mengena dan sifatnya sekedar sebagai pematangan. Dengan modal keluasan wawasan dan kreatifitas mengajar yang telah dibiasakan, guru akan lebih bisa menangkap materi-materi PPG sebagai tahapan tingkat lanjut dalam agenda besar peningkatan kompetensi guru. Ini berarti PPG bukanlah program yang semata-mata mandiri cukup untuk mengubah guru dari titik nol menuju kondisi sempurna. PPG adalah bagian dari proses panjang yang seharusnya bisa menjadi ujung tombaknya, karena dengan PPG guru selanjutnya akan langsung mendapatkan hak-hak khusus seperti sertifikat pendidik dan tunjangan.

Kesiapan dan daya dukung adalah satu paket utuh yang tidak bisa saling dipisahkan. Keduanya tertanam dalam diri setiap guru dan menjadi modal dasar mereka menghadapi PPG. Kesiapan berada dalam tataran tingkat kemungkinan aktif dalam program PPG secara penuh, sedangkan daya dukung erat kaitannya dengan totalitas guru dalam berproses selama mengikuti PPG. Kedua modal ini akan menjadi bahan input, untuk menghasilkan output yang berkompeten.

\section{Sosialisasi secara luas}

Tingkat partisipasi masyarakat dalam setiap program pemerintah selalu tergantung pada kesuksesan sosialisasi program terkait. Sosialisasi diharapkan bisa memberikan gambaran dasar pada kalangan masyarakat yang menjadi sasaran program, dalam konteks PPG sasaran yang dimaksud adalah guru. Dengan pemahaman yang benar terkait program tersebut, guru bisa memulai mempersiapkan diri secara mandiri terkait bekal-bekal pokok yang menjadi modal dalam proses PPG. Selain itu, gagalnya program PPG bisa jadi berasal dari kesalahan persepsi yang ditangkap publik.

6. Ketepatan alokasi waktu

Persoalan alokasi waktu cukup rumit penyelesaiannya, karena selalu berbenturan dengan kepentingan individu. Penyelenggara dalam hal ini perlu melihat dengan seksama keadaan peserta PPG agar mampu mengalokasikan waktu dengan tepat. Namun tanggung jawab ini 
bukan semata-mata menjadi tanggung jawab penyelenggara, entah pemerintah maupun LPTK yang ditunjuk, melainkan menjadi tanggung jawab individu guru pula. Tanggung jawab penyelenggara adalah menyesuaikan waktu pelaksanaan PPG agar tidak tumpang tindih dengan jam tugas guru sebagai pengajar di madrasah. Sedangkan tanggung jawab guru adalah mengatur ulang jadwal pribadinya agar memiliki cukup keluangan untuk berproses dalam PPG.

7. Dukungan penuh dari pemerintah

Dukungan paling nyata yang bisa dibarikan oleh pemerintah adalah pada aspek pendanaan. Dengan masa pendidikan 2 semester dan peserta dari kalangan guru berpengalaman, tentu PPG tidak bisa dilaksanakan sebagaimana program diklat seperti biasanya. PPG harus menjadi program peningkatan kompetensi guru paling jitu. Hasil PPG bisa dilihat dari signifikansi perubahan dalam diri setiap guru menuju kematangan kompetensi dalam kapasitasnya sebagai pendidik.

Tidak hanya berhenti pada seperangkat kewajiban tugas, hak-hak guru juga perlu diperhatikan. Dengan segenap dedikasinya dalam mendidik generasi muda, guru patut mendapat apresiasi setimpal dengan kesejahteraan yang memadai. Namun aspresiasi bukanlah hal yang patut dijadikan tujuan utama, melainkan sebagai reward atas kewajiban yang telah terlaksana.

\section{Bibliografi}

Asymawi, Muhammad Sa’id al., Al-Islam al-Siyasiy, Kairo, 1992, Sina Li al-Nasyr.

Aziziy, A. Qadri, Pengembanagn Ilmu-ilmu Keislaman, Jakarta, 2003, Dipertais, Kementrian Agama, Bagais, Depag RI.

Bisri, Cik Hasan, Model Penelitian Fiqh, Jilid I, Jakarta, Edisi Pertama,2003, Prenada Media.

Buwaithiy, Muhammad Said Ramadlan, Dlawabith al-Mashlahah Fi al-Syafiat al-Islamiyah, Beirut, Cet. Ke 5, 1990 M., 1410 H., Muassasah al-Risalah.

Dikki al-Bab, Ja'far, Metoda Linguistik Buku al-Kitab wa al-Qur'an, dalam Al-Kitab Wa alQur'an,karya Muhammad Syahrur, Terjemah Sahiron, Yogyakarta, 2004, ELSAQ Press.

Endraswara, Suwardi, Metodologi Penelitian Kebudayaan, Yogyakarta, 2003 Gajah Press.

Hasan Hanafi, Dirasah Islamiyah (Islamologi I) Diterjemahkan oleh Miftah Faqih, Yogyakarta, 2003, LKiS,

Ibn Taymia, Al-Radd 'ala al-Manthiqiyyin, Beirut tt. Dar al-Fikr.

Ibrahim Abu Sulaiman, Abdulwahhab, Al-Fikr al-Ushuliy, Cet. Ke I, Jeddah, 1993, 1403 H., Dar al-Syuruq.

Mahfuzh, Anas Saidi, Metodologi Penelitian, Hanya Untuk Kalangan Sendiri, tt. 
Moleong, Lexy J., Metodologi Penelitian Kwalitatif, Bandung, Cet. Ke 20, 2006, Rosdakarya. Musa, Muhammad Yusuf, Nizham al-Hukm fi al-Islam, Kairo, 1963, Dar al-Kitab al-Arabiyah. Raziy, Abu Abdillah Muhammad ibn Umar ibn Husain al., Al-Mahshul fi Ilm al-Usul Beirut tt. Dar al-Kutub al-Arabiyah.

Sa'di, al-Iraqi, Abdulhakim abdurrahman, al., Mabahits al-Illat fi al-Qiyas 'ind al-U-Shuliyyin, Beirut, Pect. Ke I, 1982 M-1406 H., Dar al-Basyair al-Islaiyah.

Sarkhasi, Muhammad ibn Ahmad ibn Abi Sahal, al., Al-Muharrar fi Ushul al-Fiqh, Beirut, tt. Dar al-Kutub al-Arabiyah.

Syalabi, Muhammad Musthafa, Ta’lil al-Ahkam, Beirut, 1981 M-1401 H., Dar al- Nahdlah alArabiyah.

Suryasumantri, Jujun S. Filsafat Ilmu Sebuah Pengantar Populer, Jakarta, 1984, Penerbit Sinar Harapan.

Ahmad Hasan, Pintu Ijtihad Sebelum Tertutup, (Bandung, Penerbit Pustaka, 1984),

Fazlur Rahman, Islamic Methodology In History, (Karache: Central Institute of Islamic Research, 1965),

Prof. DR. Muhtar Yahya, Prof.Fathur Rahman, Dasar-Dasar Pembinaan Hukum Islam, (Bandung, PT. Al - Mararif), 1997

Joseph Schacht, An Introduction to Islamic Law, (London, Oxford at the Clarendrn Press, 1971)

Muhammad Ma'ruf ad-Dawalibi, al-Madhal ila 'Ilm Usul al-Fiqh, (Ttp: Dar al-Kitab al-Jadid, 1965)

Hans George Gadamer, Truth and Method, (New York: The Seabury Press,1975).

Mahsun Fuad, "Ijtihad Ta'lili sebagai Metode Penemuan Hukum Islam (Telaah dan Perbandingannya dengan Analogi Hukum positif),” Hermenia Jurnal Kajian Islam Interdisipliner, Vol.3, No. 1, Januari-Juni 2004,

Al-Ghazalli, Al Mustasfa min Ilm al-Usul, (Beirut Dar al-Fikr, tt)

Asy-Syatibi, al-Muwafaqat fi Ushul al-Ahkam, (Ttp: Dar al-Fikr, $1341 \mathrm{H}$ ).

Abu Zahroh, Usul al-Fiqh, (ttp.: Dar al-Fikr al-'Araby, tt.)

Abdul Wahhab Khallaf, 'Ilm Ushul al-Fiqh, (Kuwait: Dar al-Qalam, tt.)

M. Hasyim Kamali, Principles of Islamic Jurisprudence, (Cambridge: The Islamic Texts Society, 1991)

Abdul Hamid A. Abu Sulayman, Towards an Islamic Theory of International Relation: New Direction for Methodology and Thought, $2^{\text {nd }}$ Edition, (Herndon, Virginia: IIIT, 1994), 
Abdul Hamid A. Abu Sulayman, Crisis in the Muslim Mind, alih bahasa Yusuf Talal Delorenzo, $1^{\text {st }}$ Edition, (Herndon, Virginia: IIIT, 1993)

Akh. Minhaji, "A Problem of Methodological Approach to Islamic Law Studies”, al-Jami'ah Journal of Islamic Studies, No. 63/VI tahun 1999

Akh. Minhaji, "Reorientasi Kajian Ushul Fiqih", al-Jami'ah Journal of Islamic Studies, No. 63/ VI tahun 1999

Syamsul Anwar, "Teori Hukum Hukum Islam al-Ghazali dan Pengembangan Metode Penemuan Hukum Islam", dalam M. Amin Abdullah et. al., Tafsir Baru Studi Islam dalam Era Multi Kultural, (Yogyakarta: Kurnia Kalam Semesta, 2002)

Wael B. Hallaq, A History f Islamic Legal Theories An Introduction to Sunni Usul al-Fiqh, (Cambridge: Cambridge University Press, 1997)

Syamsul Anwar, "Epistemologi Hukum Islam Probabilitas dan Kepastian", dalam Yudian W. Asmin (ed.), Ke Arah Fiqh Indonesia, (Yogyakarta: FSHI Fak. Syari'ah, 1994)

Abdul Hamid A. Abu Sulayman, Islamization of Knowledge General Principles and Work Plan, (Herndon, Virginia: IIIT, 1989)

A. Qodri Azizy, Eklektisisme Hukum Nasional Kompetisi Antara Hukum Islam dan Hukum Umum, (Yogyakarta: Gama Media, 2002)

Noeng Muhadjir, "Wahyu dalam Paradigma Penelitian Ilmiah Pluralisme Metodologik: Metodologi Kualitatif”, dalam Taufik Abdullah dan Rusli Karim (ed.), Metodologi Penelitian Agama Sebuah Pengantar, (Yogyakarta: Tiawa Wacana, 1989)

Juhaya S. Praja, Filsafat Hukum Islam, (Bandung: LPPM Universitas Islam Bandung, 1995),

Syamsul Anwar, "Teori Hukum Hukum Islam al-Ghazali dan Pengembangan Metode Penemuan Hukum Islam”,

Louay Safi, The Foundation of Knowlwdge, (New York: The Seabury Press,1971).

As-Sayyid as-Sabiq, Fiqh as-Sunnah, Cet. 4 (Beirut: Dar al-Fikr, 1989)

Hilman Hadikusuma, Pengantar Ilmu Hukum Adat di Indonesia, Cet. 1, (Jakarta: Mandar Maju, 1992)

Ali Parman, Kewarisan dalam Al-Qur'an Suatu Kajian Hukum dengan Pendekatan Tafsir Tematik, Cet. 1, (Jakarta: Rajawali Pers, 1994)

Ahmad Azhar Basyir, Hukum Waris Islam, Cet. 1, (Yogyakarta: UII Press, 1982)

Cik Hasan Bisri (peny.), Hukum Islam dalam Tatanaan Masyarakat Indonesia, Cet. 1, (Jakarta: Logos, 1998) 
